\title{
ANALISIS KEPATUHAN PEMILIK RUMAH KOS DALAM MEMENUHI KEWAJIBAN PAJAK HOTEL DI KELURAHAN KLEAK KECAMATAN MALALAYANG
}

\author{
Grisela V. Apita1 ${ }^{1}$ Sifrid S. Pangemanan², Jessy D. L. Warongan ${ }^{3}$ \\ ${ }^{1,2,3}$ Fakultas Ekonomi dan Bisnis, Jurusan Akuntansi, Universitas Sam Ratulangi, Jl. Kampus Bahu, Manado, \\ 95115, Indonesia \\ E-mail : griselaapita@yahoo.co.id
}

\begin{abstract}
One of the biggest local sources of regional income in Regional Original Revenue (PAD) is from the tax and retribution sector, where taxes are mandatory contributions that must be paid to the state. Tax payments have never been spared from various problems, one of which is the problem of compliance from taxpayers to fulfill obligations in paying taxes. The problems in this study include: (1) how the compliance of boarding house owners in meeting hotel tax obligations, (2) what are the obstacles in fulfilling boarding house owner compliance in meeting hotel tax obligations. The purpose of this study is to: (1) determine the compliance of boarding house owners in meeting hotel tax obligations, (2) constraints in fulfilling homeowner's compliance in meeting hotel tax obligations. The analytical method used in this research is descriptive qualitative in which the purpose of each data collected is analyzed then drawn conclusions descriptively. The results obtained from this study are that boarding house owners have not complied in fulfilling their hotel tax obligations, obstacles that affect the compliance of boarding house owners, among others: awareness of taxpayers, tax knowledge and understanding, tax socialization, and service tax. Boarding house owners are expected to increase awareness of their taxex so they can carry out their obligations as taxpayers.
\end{abstract}

Keywords: regional income; local tax; hotel tax; boarding house tax; tax compliance

\section{PENDAHULUAN}

Pada hakekatnya pembangunan Nasional diarahkan pada dua aspek yakni pembangunan material dan pembangunan spiritual berdasarkan Pancasila dan Undang Undang Dasar 1945. Kedua aspek yang menjadi sasaran pembangunan tersebut merupakan suatu kesatuan yang harus dilasanakan secara bersamaan dan seimbang di seluruh tanah air Indonesia, dalam upaya untuk mengurangi kepincangan terhadap jalannya roda pembangunan. Sekarang ini pemerintah sedang giat - giatnya menyelenggarakan berbagai program pembangunan, dalam rangka peningkatan taraf hidup, kecerdasan dan kesejahteraan masyarakat. Dalam menyelenggarakan program pembangunan tersebut pemerintah mendapatkan sumber dana dari Pendapatan Asli Daerah (PAD).

Untuk dapat meningkatkan dan mengoptimalkan Pendapatan Asli Daerah (PAD) khususnya dari sektor pajak pemerintah dalam hal ini khususnya Pemerintah Daerah Kota Manado mengeluarkan Peraturan Daerah Kota Manado Nomor 2 tentang Pajak Daerah. Dalam Peraturan Daerah Kota Manado Nomor 2 Tahun 2011 yang didalamnya mengatur salah satunya tentang pajak hotel, dimana pajak hotel dikenakan atas pelayanan yang disediakan dari pihak hotel. Pengertian hotel yang dimaksud adalah fasilitas penyedia jasa penginapan / peristirahatan termasuk jasa terkait lainnya dengan dipungut bayaran, yang mencakup juga motel, losmen, gubuk pariwisata, pesanggrahan, rumah penginapan dan sejenisnya, serta rumah kos dengan jumlah kamar lebih dari 10 kamar. 
Provinsi Sulawesi Utara khususnya Kota Manado sedang melaksanakan pembangunan dari waktu ke waktu dan telah menunjukkan pertumbuhan dan perkembangannya diberbagai segi dan sektor yang pada hakikatnya mencakup seluruh aspek kehidupan manusia. Dan salah satu sektor yang menonjol pertumbuhan dan perkembangannya adalah dalam pembangunan hotel, penyedia rumah kos, rumah kontrakan, dan penginapan. Yang menjadi salah satu kawasan strategis dalam pembangunan rumah kos dan rumah kontrakan yaitu Kelurahan Kleak Kecamatan Malalayang dimana Kawasan atau wilayah Kelurahan Kleak Kecamatan Malalayang menjadi strategis karena menjadi pusat tempat pendidikan dimana terdapat Universitas Negeri dan Universitas Swasta yang ada sehingga kebutuhan rumah kos, rumah kontrakan dan penginapan sangat dibutuhkan.

Disadari bahwa seiring dengan pertumbuhan dan perkembangan rumah kos, tidaklah lepas dari permasalahan - permasalahan yang ada baik permasalahan yang berasal dari pemilik rumah kos ataupun Pemerintah baik ditingkat Kelurahan, Kecamatan, Kota dan Provinsi Sulawesi Utara. Permasalahan yang dimaksud antara lain kontribusi wajib pajak dalam hal ini iuran yang harusnya dibayar oleh pemilik kos dengan jumlah kamar lebih dari 10 kamar.

Permasalahan utama dalam pajak rumah kos adalah pemilik rumah kos belum membayar pajak atas rumah kos disebabkan antara lain ketidaktahuan akan adanya pajak rumah kos itu sendiri, serta penyebab lainnya seperti pemilik rumah kos berpendapat dengan adanya pajak rumah kos lebih membebani pemilik untuk membayar karena banyaknya pajak serta retribusi yang nantinya harus dibayar oleh pemilik rumah kos, semua hal diatas berkaitan dengan kepatuhan pajak dari pemilik rumah kos dalam melaksanakan hak dan kewajiban perpajakannya.

\section{TINJAUAN PUSTAKA}

Akuntansi. Menurut American Accounting Association (AAA) akuntansi merupakan kegiatan mengidentifikasikan, mengukur, dan melaporkan informasi ekonomi untuk memungkinkan dilakukan penilaian serta pengambilan keputusan secara jelas dan tegas bagi pihak yang menggunakan informasi (Susilowati, 2016 : 1). Peraturan Pemerintah No. 71 tahun 2010, Akuntansi adalah proses identifikasi, pencatatan, pengukuran, pengklasifikasian, pengikhtisaran transaksi dan kejadian keuangan, penyajian laporan, serta pengiterpretasian atas lainnya.

Pajak. Pajak merupakan iuran yang wajib, berupa uang atau barang yang dipungut oleh peguasa berdasarkan norma hukum, guna mencapai kesejahteraan umum (Muljono, 2010 : 1). Pajak sebagai suatu kewajiban menyerahkan sebagian dari pada kekayaan kepada negara disebabkan suatu keadaan, kejadian dan perbuatan yang memberikan kedudukan tertentu, tetapi bukan sebagai hukuman dalam peraturan - peraturan yang ditetapkan pemerintah serta dapat dipaksakan tetapi tidak ada jasa timbal balik dari negara secara langsung untuk memelihara kesejahteraan umum (Mardiasmo, 2013 :1). Lembaga pemungutan pajak dibagi atas 2 yaitu pajak pusat dan pajak daerah.

Pajak Daerah. Dalam Undang - Undang Nomor. 28 Tahun 2009 tentang Pajak Daerah dan Retribusi Daerah bahwa pajak daerah dan retribusi daerah merupakan salah satu sumber pendapatan daerah yang penting guna membiayai pelaksanaan pemerintahan daerah. Pajak daerah adalah kontribusi wajib kepada daerah yang terutang oleh orang pribadi atau badan yang bersifat memaksa yang berdasarkan undang - undang, dengan tidak mendapatkan imbalan secara langsung dan digunakan untuk keperluan daerah dan untuk sebesar - besarnya untuk kemakmuran rakyat.

Pajak Hotel. Peraturan Daerah Kota Manado Nomor 2 Tahun 2011 tentang pajak daerah menjelaskan pajak hotel adalah pajak atas pelayanan yang disediakan oleh hotel. Pengertian hotel yang dimaksud adalah fasilitas penyedia jasa, penginapan / peristirahatan, 
termasuk juga rumah kos dengan jumlah kamar lebih dari 10 kamar. Subjek pajak dari pajak hotel kategori rumah kos adalah pemilik rumah kos.Objek pajak dari pajak hotel kategori rumah kos adalah penghasilan atau pendapatan yang diperoleh dari usaha persewahan wajib pajak selaku pengelola rumah kos. Tarif pengenaan pajak atas rumah kos sebagaimana diatur dalam Perda Kota Manado Nomor. 2 Tahun 2011 adalah sebesar 5 \% (lima persen) yang dikenakan dari atas penghasilan yang diterima oleh wajib pajak atau jumlah pendapatan yang didapat atau diterima dari persewaan kamar kosnya.

Kepatuhan Wajib Pajak. Kepatuhan wajib pajak merupakan suatu kemauan dan kesadaran wajib pajak mengenai kewajibannya dalam bidang perpajakan. Kemauan dan kesadaran wajib pajak akan menjadi dasar dalam perubahan sikap wajib pajak untuk memenuhi kewajiban dan hak perpajakannya. Menurut Rustiyaningsih (2011) kepatuhan perpajakan juga dapat diartikan sebagai suatu keadaan yang mana wajib pajak patuh dan mempunyai kesadaran dalam memahami kewajiban perpajakannya sesuai dengan ketentuan peraturan perundang - undangan. Kepatuhan wajib pajak dapat dipengaruhi oleh 2 hal, yaitu faktor internal dan faktor eksternal, penelitian yang dilakukan oleh Dhanesworo didapatkan faktor - faktor yang mempengaruhi kepatuhan wajib pajak yaitu antara lain kesadaran wajib pajak, pengetahuan wajib pajak, dan pelayanan fiskus.

Pemilik Rumah Kos. Pemilik menunjuk kepada seseorang atau individu yaitu yang mempunyai atau memiliki, Sedangkan Rumah kos yang ada di dalam Kamus Besar Bahasa Indonesia memiliki arian lain yaitu : In-de-kos adalah tinggal dirumah orang lain dengan atau tanpa makan (dengan membayar setiap bulan); memondok;. Berdasarkan pengertian tersebut diatas, jelas bahwa yang dimaksud dengan rumah kos atau indekos yakni sebuah tempat tinggal atau rumah yang disewakan kepada seseorang dengan membayar biaya sewa kepada pengelola atau pemilik.

\section{METODE PENELITIAN}

Jenis Penelitian. Jenis penelitian yang digunakan adalah penelitian kualitatif deskriptif. Penelitian kualitatif juga sering diistilahkan dengan penelitian atau inkuiri naturalistic atau alamiah, etnografi, interaksionis simbolik, dan prespektif ke dalam (Bogdan dan Biklen, dikutip dalam Moleong, 2017 : 3). Pendekatan ini dipakai untuk melacak berbagai data yang berkaitan dengan pengetahuan dari pemilik rumah kos terhadap pajak rumah kos di Kelurahan Kleak Kecamatan Malalayang, dengan menghasilkan data deskriptif yang berupa kata yang tertulis.

Metode Pengumpulan Data. Dalam melakukan pengumpulan data beserta informasi - informasi berkaitan dengan penelitian ini dilakukan dengan melalui tahap Observasi dan wawancara. Observasi dilakukan pengamatan atau observasi atas jumlah dari kamar rumah kos yang ada beserta pengelolaan rumah kos. Wawancara digunakan sebagai teknik dari pengumpulan data karena peneliti ingin melakukan untuk menentukan permasalahan yang harus diteliti.

Metode dan Proses Analisis. Metode analisis data pada penelitian ini menggunakan analisis deskriptif kualitatif. Dalam menganalisis data hasil penelitian dilakukan sejak kegiatan awal penelitian dan berakhir ketika semua data yang diperlikan sesuai fokus penelitian sudah terkumpul dan dalam artian sesudah rampung sebelumnya. Adapun tahap tahap yang dilakukan dalam menganalisis data adalah sebagai berikut :

1. Melakukan pemaparan data dan observasi tentang pemungutan pajak rumah kos diantaranya meliputi : bagaimana proses pemungutan pajak rumah kos, kriteria rumah kos yang dikenakan pajak rumah kos.

2. Mengumpulkan data dan informasi terkait dengan kepatuhan pemilik rumah kos terhadap pajak rumah kos kepada pemilik rumah kos, dengan melakukan wawancara kepada pemilik rumah kos selaku pembayar pajak. 
3. Mengidentifikasi hal - hal apa yang dapat mempengaruhi kepatuhan pemilik rumah kos terhadap pajak rumah kos.

4. Menyimpulkan kepatuhan serta hal - hal yang mempengaruhi kepatuhan pemilik rumah kos terhadap pajak rumah kos.

5. Melengkapi data dengan cara mengkaji ulang data baik berupa hasil observasi, hasil wawancara.

6. Menjabarkan seluruh hasil penelitian secara terperinci, kemudian menyusun dalam bentuk laporan.

\section{HASIL PENELITIAN DAN PEMBAHASAN}

Gambaran Umum Kelurahan Kleak. Kelurahan Kleak merupakan kelurahan yang berada di Kecamatan Malalayang di Kota Manado, Sulawesi Utara. Dengan jumlah kepala keluarga $1500 \mathrm{KK}$ dan jumlah penduduk 5197 jiwa.

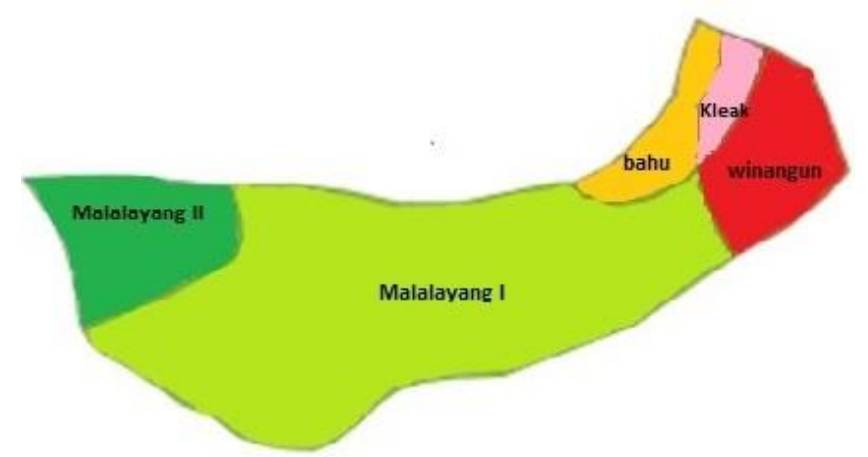

Gambar 1. Peta Kecamatan Malalayang

Sumber : Data kelurahan Kleak, 2019

Kelurahan Kleak yang berada di Kecamatan Malalayang merupakan wilayah yang berada diwilayah administrasi Kecamatan Malalayang yang disebelah utara berbatasan dengan Kelurahan Sario Tumpaan, sebelah selatan berbatasan dengan Kelurahan Batu Kota, disebelah timur berbatasan dengan kelurahan Karombasan Utara, dan disebelah barat berbatasan dengan kelurahan Bahu. Selain berada dipusat wilayah administrasi dan pusat kota wilayah Kelurahan Kleak juga dikelilingi dengan Universitas Sam Ratulang, Universitas Pembangunan Indonesia yang hal ini mengakibatkan wilayah Kelurahan Kleak menjadi lokasi yang strategis untuk menjadi tempat tinggal baik rumah kos ataupun penginapan yang sangat dibutuhkan bagi pelajar, mahasiswa dan pendatang.

\subsection{Hasil Penelitian}

\section{Kepatuhan Wajib Pajak}

Wajib Pajak Memiliki NPWPD. Berdasarkan hasil wawancara dari 10 informan didapatkan hasil bahwa seluruh informan selaku pemilik rumah kos yang wajib membayar pajak daerah belum memiliki NPWPD, seperti yang dikatakan oleh informan 7 yang bahwa informan baru mendengan akan adanya NPWPD setelah peneliti menayakan dan belum mengetahui lebih jelas lagi apa itu NPWPD. Adapun informan 2 juga mengatakan bahwa mereka tidak memiliki NPWPD dikarenakan tidak mengetahui akan adanya NPWPD. hasil wawancara dengan para informan secara keseluruhan para informan telah memiliki NPWPD sebagai identitas pajaknya.

Pemahaman Atas Pajak Rumah Kos. Berdasarkan hasil penelitian atas pemahaman pemilik rumah kos yang memiliki kamar lebih dari 10 kamar sebagai wajib pajak hotel, dimana sebagian besar dari informan belum mengetahui akan adanya pajak rumah kos yang diatur berdasarkan dengan Peraturan Daerah Kota Manado Nomor. 2 Tahun 2011, seperti hasil wawancara dengan informan 1 mengenai pajak rumah kos mengatakan bahwa beliau 
selama ini belum mengetahui akan adanya pajak rumah kos disebabkan belum ada pemberitahuan dari pemerintah setempat tentang adanya pajak rumah kos tersebut, informan 1 juga mengatakan mengetahui pajak rumah kos setelah peneliti melaksanakan wawancara tentang pajak rumah kos. Sebagian besar dari para informan menjawab bahwa selama ini mereka tidak mengetahui akan adanya pajak atas rumah kos. Jawaban sebaliknya dikatakan oleh informan 2 yang mengatakan bahwa beliau sudah mengetahui akan adanya pajak atas rumah kos dikarenakan beliau sudah pernah mengikuti sosialisasi yang diadakan oleh pemerintah tetapi setelah sosialisasi tidak ada kelanjutan tentang pajak rumah kos dikarenakan banyak yang keberatan akan adanya pajak rumah kos. Berdasarkan hasil penelitian pemahaman pajak rumah kos dari para pemilik kos dapat disimpulkan bahwa para pemilik rumah kos belum mengetahui dan memahami betul pajak rumah kos.

Wajib Pajak Membayar Pajak Rumah Kos. Berdasarkan hasil wawancara bersama informan 5 mengenai pembayaran pajak rumah kos informan mengatakan bahwa selama ini hanya membayar pajak rumah yaitu Pajak Bumi dan Bangunan (PBB) yang dibayarkan pertahun yang secara langsung dibayar kepada kepala lingkungan setempat tetapi untuk pajak rumah kos informan belum pernah membayar. Jawaban yang sama juga dikatakan oleh informan 6 yaitu beliau selama ini hanya membayar PBB saja dan sering kali membayar tidak tepat waktu, sedangkan untuk pembayaran pajak rumah kos itu sendiri informan belum pernah membayar dikarenakan baru mendengar akan adanya pajak rumah kos dan informan juga tidak mengetahui mekanisme pembayaran pajak rumah kos itu sendiri. Berdasarkan hasil wawancara secara keseluruhan informan mengutarakan hal yang sama seperti informan 5 dan informan 6 bahwa mereka selama ini hanya membayar pajak atas bumi dan bangunan mereka belum pernah membayar pajak atas rumah kos.

Wajib Pajak Melaporkan SPTPD. Hasil penelitian didapatkan dimana secara keseluruhan dari informan mengatakan hal yang sama seperti yang dikatakan oleh informan 1, mengatakan bahwa informan tidak melaporkan SPTPDnya hal ini disebabkan informan tidak mengetahui cara mekanisme pelaporan dari SPTPD. Hasil wawancara dari informan 6 mengatakan bahwa informan tidak melaporkan SPTPDnya dikarenakan belum ada pemberitahuan dari pemerintah tentang cara melaporkan SPTPD. Berdasarkan hasil wawancara dengan para informan dapat disimpulkan bahwa para pemilik rumah kos belum pernah melaporkan SPTPD dikarenakan tidak tau mekanisme dari pelaporan SPTPD.

\section{Kendala Yang Mempengaruhi Kepatuhan Wajib Pajak}

Kesadaran Wajib pajak Salah satu kendala terbesar dalam pemungutan pajak adalah kesadaran dari wajib pajak. Penulis berpendapat kesadaran dari pemilik rumah kos selaku wajib pajak sangat mempengaruhi kepatuhan pajak dapat dilihat dari hasil penelitian sebelumnya dimana para pemilik rumah kos selaku wajib pajak belum memiliki kesadaran akan kewajiban perpajakan yang harus dilaksanakan, salah satu kriteria wajib pajak yang memiliki kesadaran pajak apabila wajib pajak dapat menghitung, membayar, dan melaporkan pajak secara sukarela dan benar. Dalam penelitian ini dapat dilihat bahwa para pemilik rumah kos selaku wajib pajak dapat dikatakan masih belum memiliki kesadaran akan pajaknya, dapat dilihat dari para pemilik rumah kos masih belum menghitung sendiri pajak yang harus dibayarkan seperti yang dikatakan oleh informan 8 dimana informan belum pernah menghitung pajaknya sendiri dikarenakan selama ini hanya membayar pajak langsung kepada kepala lingkungan yang ada. Dengan demikian dapat disimpulkan bahwa kesadaran akan pajak sangatlah berpengaruh akan kepatuhan dari para wajib pajak untuk dapat melaksanakan kewajibannya.

Pengetahuan dan Pemahaman Wajib Pajak. Pengetahuan dan pemahaman dari wajib pajak dapat mempengaruhi kepatuhan dari wajib pajak, hal ini dapat dilihat dari penelitian yang telah dilaksanakan, dimana secara keseluruhan para pemilik rumah kos 
selaku wajib pajak tidak membayar pajak rumah kos dikarenakan tidak mengetahui dan masih memiliki pemahaman yang kurang akan pajak rumah kos, seperti yang dikatakan oleh informan 4, dimana informan mengatakan bahwa beliau tidak mengetahui akan adanya pajak rumah kos, ketidak tahuan akan adanya pajak rumah kos dari para pemilik rumah kos mengakibatkan para pemilik rumah kos belum memenuhi kewajibannya sebagai wajib pajak atas pajak hotel kategori rumah kos. Dengan demikian dapat ditarik kesimpulan dimana pengetahuan dan pemahaman dari wajib pajak dapat menjadi hal yang penting bagi wajib pajak dalam memenuhi kepatuhannya sebagai wajib pajak.

Sosialisasi. Penyebab sosialisasi menjadi salah satu hal penting yang mempengaruhi kepatuhan dari wajib pajak adalah dari sosialisasi yang dilaksanakan oleh pemerintah masyarakat dapat mengetahui akan adanya pemberitahuan tentang pajak itu sendiri, berdasarkan hasil penelitian secara keseluruhan para pemilik rumah kos selaku wajib pajak belum pernah mengikuti sosialisasi dari pemerintah tentang pajak, khususnya tentang pajak hotel kategori rumah kos hal ini mengakibatkan para pemilik rumah kos tidak menjalankan kewajibannya atas pajak rumah kos dikarenakan belum mengetahui akan adanya pajak rumah kos, hal ini dapat dilihat dari hasil wawancara dari informan 4 mengatakan bahwa beliau belum pernah mengikuti sosialisasi dan belum pernah mendapatkan undangan untuk mengikuti sosialisasi, ketidak ikut sertaan informan 4 dalam sosialisasi mengakibatkan informan tidak mengetahui akan adanya pajak rumah kos. Dapa dilihat dari hasil penelitian dimana pemilik rumah kos belum pernah mengikuti sosialisasi, dengan demikian dapat dilihat disini sosialisasi merupakan salah satu hal penting dalam menjalankan kepatuhan sebagai wajib pajak.

Pelayanan Fiskus. Kepatuhan wajib pajak dalam memenuhi kewajiban membayar pajak dapat tergantung juga pada pelayanan fiskus. Pelyanan fiskus dapat diartikan sebagai pelayanan yang diberikan oleh Direktorat Jenderal Pajak kepada wajib pajak untuk membantu wajib pajak memenuhi kewajiban perpajakannya. Berdasarkan dari hasil penelitian yang didapat dimana para pemilik rumah kos selaku wajib pajak belum pernah mengikuti sosialisasi tentang pajak rumah kos dan ada juga yang sudah pernah mengikuti sosialisasi tentang pajak rumah kos, dapat dilihat bahwa pelayanan fiskus yang belum optimal dalam melaksanakan sosialisasi tentang pajak rumah kos, yang mengakibatkan sebagian besar dari para pemilik rumah kos belum mengetahui dan memahami akan adanya pajak rumah kos.

\subsection{Pembahasan}

\section{Kepatuhan Wajib Pajak}

Wajib Pajak Memiliki NPWPD. Berdasarkan penelitian yang telah dilaksanakan didapatkan hasil dimana seluruh informan pemilik rumah kos selaku wajib pajak yang harus membayar pajak daerah belum memiliki NPWPD sebagai identitas dalam melaksanakan kewajibannya sebagai wajib pajak daerah. Para informan belum memiliki NPWPD dikarenakan para informan selaku pemilik rumah kos belum mengetahui dan memahami kegunaan dari NPWPD. Dengan demikian dapat disimpulkan bahwa para pemilik rumah kos belum patuh hal ini dikarenakan para pemilik rumah kos belum memiliki NPWPD sebagai identitas pajak daerahnya.

Pemahaman Atas Pajak Rumah Kos. Berdasarkan hasil penelitian didapatkan hasil dimana 2 dari 10 informan selaku pemilik rumah kos yang diwawancarai mengenai pajak rumah kos telah mengetahui akan adanya pajak rumah kos, 2 pemilik rumah kos yang menjadi informan mengetahui akan adanya pajak rumah kos dari sosialisasi yang telah diadakan oleh pemerintah. Sedangkan hasil penelitian dari 8 informan lainnya belum mengetahui akan adanya pajak rumah kos dikarenakan selama ini hanya mengetahui akan adanya $\mathrm{PBB}$, selain itu para informan selaku pemilik rumah kos belum mengetahui akan adanya pajak rumah kos sendiri dikarenakan kurangnya sosialisasi yang dilakukan oleh 
pemerintah akan adanya pajak hotel kategori rumah kos. Dengan demikian hasil penelitian menunjukkan bahwa para pemilik rumah kos belum patuh hal ini dikarenakan para pemilik rumah kos belum mengetahui akan kewajiban mereka dalam pembayaran pajak rumah kos.

Wajib Pajak Membayar Pajak Rumah Kos. Berdasarkan hasil penelitian didapat bawah ke - 10 pemilik rumah kos selaku wajib pajak rumah kos tidak membayar pajak rumah kosnya hal ini disebabkan akan ketidaktahuan dari informan selaku pemilik rumah kos yang tidak mengetahui akan adanya pajak yang dikenakan atas rumah kosnya, para pemilik rumah kos selama ini hanya membayar PBB. Dengan demikian para pemilik rumah kos dapat dikatakan belum patuh akan pajak hotel kategori rumah kos.

Wajib Pajak Melaporkan SPTPD. Berdasarkan hasil penelitian yang telah dilaksanakan didapatkan hasil dimana ke 10 informan selaku wajib pajak rumah kos belum pernah melaporkan SPTPDnya, hal ini dikarenakan pemilik rumah kos belum mengetahui mekanisme pelaporan SPTPD. Berdasarkan hasil penelitian para pemilik rumah kos masih memiliki tingkat kesadaran yang rendah akan menjalankan kewajibannya melaporkan SPTPD setiap tahun pajak, hal ini menunjukkan bahwa para pemilik rumah kos selaku wajib pajak masih belum patuh.

\section{Kendala Yang Mempengaruhi Kepatuhan Wajib Pajak}

Kesadaran Wajib pajak. Dari hasil penelitian dapat dilihat bahwa para pemilik rumah kos selaku wajib pajak belum memiliki kesadaran yang tinggi akan pajak hotel kategori rumah kos, dengan demikian Wajib pajak rumah kos harus memiliki kesadaran akan peraturan yang ada dan untuk membayar pajak atas usaha yang dijalankannya, ketika setiap wajib pajak sadar akan kewajibannya sebagai wajib pajak maka akan tercipta kepatuhan wajib pajak yang baik. Hasil penelitian ini selaras dengan penelitian yang telah dilakukan oleh Ardhyanto (2015) dimana dalam penelitian tersebut menunjukkan bahwa kesadaran dari wajib pajak berpengaruh signifikan terhadap kepatuhan wajib pajak, hal ini dapat diartikan kesadaran dari wajib pajak merupakan hal yang dapat berpengaruh terhadap kepatuhan wajib pajak. Julianti (2014) mengatakan dalam penelitiannya kesadaran membayar pajak berpengaruh positif terhadap kemauan membayar pajak, dimana secara tidak langsung kesadaran membayar pajak berpengaruh pada kepatuhan pajak. Kesadaran akan membayar pajak merupakan hal utama yang harus dimiliki oleh para wajib pajak, agar dapat melaksanakan kepatuhan pajak yang baik seperti pembayaran pajak tepat waktu, sesuai dengan jumlah yang harus dibayar dan tidak pernah mendapatkan surat teguran.

Pengetahuan dan Pemahaman Wajib Pajak. Dalam hasil penelitian dapat dilihat bahwa pemilik rumah kos tidak mengetahui dan paham akan adanya pajak rumah kos hal ini berpengaruh dalam pelaksanaan kepatuhan pajaknya. Semakin paham wajib pajak dalam memahami peraturan perpajakan maka akan semakin sedikit kemungkinan wajib pajak untuk lalai dalam pembayaran pajaknya. Hasil penelitian yang sama juga diutarakan dalam penelitian oleh Dhanesworo (2016) dimana hasil penelitian menunjukkan bahwa pengetahuan wajib pajak berpengaruh signifikan dan positif terhadap kepatuhan wajib pajak dalam membayar pajak hotel kategori rumah kos, dalam penelitian Ardhyanto (2015) menunjukkan hasil yang sama dimana pengetahuan wajib pajak berpengaruh signifikan terhadap kepatuhan wajib pajak, dapat diartikan bahwa pengetahuan dari wajib pajak dapat mempengaruhi kepatuhan dari wajib pajak itu sendiri.

Sosialisasi. Berdasarkan hasil penelitian para pemilik rumah kos masih banyak yang belum pernah mengikuti sosialisasi degan demikian kurangnya sosialisasi dari pemilik rumah kos dapat mengakibatkan kurangnya pengetahuan akan pajak dan mempengaruhi kepatuhan dari para pemilik rumah kos. Kurangnya pengetahuan dan wawasan karena rendahnya sosialisasi perpajakan akan mengakibatkan wajib pajak tidak memahami bagaimana caranya melaksanakan kewajiban perpajakan dan pada akhirnya tidak melaksanakan kewajiban 
perpajakannya. Penelitian ini mendapatkan hasil yang sejalandengan penelitian yang dilakukan oleh Pekerti (2015) dimana dalam hasil penelitian menunjukan bahwa sosialisasi perpajakan itu sendiri memiliki pengaruh besar terhadap kepatuhan wajib pajak melalui kewajiban wajib pajak. Sosialisasi sangat berpengaruh terhadap kepatuhan wajib pajak, sosialisasi telah banyak memberikan pengeritian tentang semua hal yang berkaitan dengan pajak.

Pelayanan Fiskus. Berdasarkan dari hasil penelitian yang didapat dimana para pemilik rumah kos selaku wajib pajak belum pernah mengikuti sosialisasi tentang pajak rumah kos dan ada juga yang sudah pernah mengikuti sosialisasi tentang pajak rumah kos, dapat dilihat bahwa pemberian pelayanan dari fiskus terhadap wajib pajak rumah kos belumlah optimal dimana, masih belum meratanya sosialisasi yang dilakukan oleh fiskus tentang pajak rumah kos kepada para pemilik rumah kos. Hasil penelitian sejalan dengan penelitian yang dilakukan oleh Jatmiko (2006) dimana pelayanan fiskus memiliki koefisien dengan tanda positif, hal ini menunjukkan bahwa pengaruh sikap wajib pajak terhadap pelayanan fiiskus terhadap variabel kepatuhan wajib pajak adalah positif, dimana pelayanan fiskus dapat berpengaruh terhadap kepatuhan wajib pajak dan masih dimungkinkan untuk dilakukan peningkatan terhadap pelayanan fiskus. Hasil penelitian yang sama juga diutarakan dalam penelitian Mutia (2014) dimana pelayanan fiskus berpengaruh signifikan positif terhadap kepatuhan wajib pajak, yang berarti pelayanan fiskus dapat berpengaruh dalam kepatuhan membayar pajak.

\section{KESIMPULAN DAN SARAN}

\subsection{Kesimpulan}

Berdasarkan hasil penelitian dan pembahasan sebelumnya maka penulis dapat menarik kesimpulan sebagai berikut :

1. Kepatuhan wajib pajak secara garis besar adalah suatu kemauan dan kesadaran wajib pajak mengenai kewajibannya dalam bidang perpajakan. Kepatuhan formal wajib pajak dapat memenuhi kepatuhannya dengan selalu menghitung, membayar, dan menyampaikan SPTPD.

2. Pemilik rumah kos belum mengetahui akan adanya pajak rumah kos yang sebagaimana diatur dalam Peraturan Daerah Kota Manado Nomor 2 Tahun 2011 yang mengatur tentang Pajak Daerah, salah satunya mengatur tentang pajak rumah kos, yang dimana pajak rumah kos dikenakan jika rumah kos memiliki lebih dari 10 (sepuluh) kamar.

3. Pemilik rumah kos selaku wajib pajak hotel Kategori rumah kos belum patuh akan adanya pajak hotel kategori rumah kos, dikarenakan para pemilik rumah kos selaku wajib pajak belum melaksanakan kewajibannya sebagai wajib pajak.

4. Kendala yang mempengaruhi kepatuhan dari pemilik rumah kos antara lain : kesadaran dari wajib pajak untuk melaksanakan kewajiban pajaknya, pengetahuan dan pemahaman

5.2. Saran dari wajib pajak tentang pajak, sosialisasi tentang pajak, dan pelayanan fiskus. berikut :

Berdasarkan penelitian yang dihasilkan oleh penulis maka dapat ditarik saran sebagai

1. Untuk pemilik rumah kos sebagai wajib pajak diharapkan agar dapat meningkatkan kesadaran akan pajaknya, agar dapat melaksanakan kewajibannya sebagai wajib pajak.

2. Untuk Pemerintah diharapkan agar lebih giat dalam meningkatkan upaya - upaya untuk meningkatkan kepatuhan wajib pajak, seperti melakukan penyuluhan dan sosialisasi secara menyeluruh kepada pemilik - pemilik rumah kos.

3. Petugas pajak diharapkan agar dapat lebih memonitoring pelaksanaan self assessment system supaya dapat meningkatkan kepatuhan wajib pajak. 
4. Untuk peneliti selanjutnya diharapkan agar dapat memperluas penelitian bukan hanya terbatas di Kota Manado, namun dapat meneliti di luar Kota sehingga hasil yang di hasilkan lebih banyak dan maksimal.

\section{DAFTAR PUSTAKA}

Ardhyanto, I, A. (2015). Analisis Kepatuhan Wajib Pajak Dalam Membayar Pajak Hotel Kategori Kos (Studi Empiris Wajib Pajak Kota Semarang). Jurnal Riset Akuntansi $\begin{array}{llllll}\text { Keuangan. } & 2 & \text { (3). } & 14 & - & 24 .\end{array}$ http://eprints.undip.ac.id/64309/1/11._Kepatuhan_Pajak.pdf. 16 Mei 2019.

Dhanesworo, H. (2016). Faktor - Faktor yang Mempengaruhi Tingkat Kepatuhan Wajib Pajak Dalam Membayar Pajak Hotel Kategori Rumah Kos (Studi Kasus Pada Pemilik Usaha Kos - Kosan di Kota Yogyakarta dan Kabupaten Sleman). Skripsi. Universitas Muhammadiyah Yogyakarta, Indonesia. http://repository.umy.ac.id/handle/123456789/5488.

Jatmiko. A. N. (2006). Pengaruh Sikap Wajib Pajak Pada Pelaksanaan Sanski Denda, Pelayanan Fiskus Dan Kesadaran Perpajakan Terhadap Kepatuhan Wajib Pajak ( StudyEmipis Terhadap Wajib Pajak Orang Pribadi Di Kota Semarang). Thesis. Universitas diponegoro. Semarang. http://eprints.undip.ac.id/15261/1/Agus_Nugroho_Jatmiko.pdf

Kamus Besar Bahasa Indonesia. (2011). Badan Pengembangan dan Pembinaan Bahasa. Kementerian Pendidikan dan Kebudayaan. Jakarta.

Mardiasmo. (2013). Perpajakan Edisi Revisi. Yogyakarta: Penerbit Andi.

Mulyono, D. 2010. Hukum Pajak, Konsep, Aplikasi, dan Penuntun Praktis. Yogyakarta: Penerbit Andi.

Mutia. S. P. T. (2018). Pengaruh Sanksi Perpajakan Kesadaran Perpajakan,Pelayanan Fiskus, Tingkat Pemahaman Terhadap Kepatuhan Wajib Pajak Orang Pribadi (Study Empiris Pada Wajib Pajak Orang Pribadi Yang Terdaftar di KPP Pratama Padang).Skripsi. Universitas negeri padang. Sumatera Barat. http://ejournal.unp.ac.id/students/index.php/akt/article/view/902/652

Moleong. L. J. (2017). Metodologi Penelitian Kualitatif. Edisi revisi. Bandung: PT. Remaja Rosakarya.

Pekerti. T. C. (2015). Pengaruh sosialisasi perpajakan terhadap pemahaman wajib pajak yang mendukung kepatuhan wajib pajak (Studi Pada Wajib Pajak Hotel Atas Rumah Kos Terdaftar DI Dinas Pendapatan Daerah Kota Malang). Jurnal Perpajakan. 7(1). 1 10.http://perpajakan.studentjournal.ub.ac.id/index.php/perpajakan/article/view/215/21 0

Peraturan Daerah Kota Manado Nomor 2 Tahun 2011 tentang Pajak daerah. Lembar Daerah Kota Manado Tahun 2011 Nomor 2 . Manado.

Peraturan Pemerintah Nomor 71 Tahun 2010 tentang Standar Akuntansi Pemerintahan.

Rustiyaningsih. S. (2011). Faktor - Faktor yang Mempengaruhi Kepatuhan Wajib Pajak .

Widya Warta Jurnal Ilmiah. $2(1) . \quad 44 \quad-\quad 54$. http://portal.widyamandala.ac.id/jurnal/index.php/warta/article/view/73

Susilowati. (2016). Mahir Akuntansi Perusahaan Jasa dan Dagang. Yogyakarta: Kalimedia. Wulandari, N. Djudi, M. dan Dewantara, R, Y. (2015). Analisis Kepatuhan Wajib Pajak Terhadap Peraturan Daerah Kota Malang Nomor 16 Tahun 2016 Kategori Pajak Rumah Kos. Jurnal Perpajakan (JEJAK). $7(1) . \quad 1 \quad$ - 9. http://perpajakan.studentjournal.ub.ac.id/index.php/perpajakan/article/view/216/211. Undang - undang Nomor 28 Tahun 2009 tentang Pajak Daerah dan Retribusi Daerah. 